\title{
PENGARUH GOOD CORPORATE GOVERNANCE DAN PENGUNGKAPAN CORPORATE SOCIAL RESPONSIBILITY TERHADAP NILAI PERUSAHAAN
}

Oleh :

\author{
Leni Yuliyanti
}

\begin{abstract}
The objective of this research was to discover the effects of Good Corporate Governance(CGC) and Corporate Social Responsibility (CSR) disclosure on firm value. This studyemployed a descriptive-verifying method. The population in this study was the companies listedin the IICGP ranking, selected through purposive sampling technique. The data collectiontechnique utilized documentation study with descriptive analysis technique and classicalassumption tests; $F$ test and t test. The results of the study demonstrated that GCG gavesignificant positive effect on firm value, CSR disclosure gave significant positive effect on firmvalue, as well as GCG and CSR disclosure gave significant positive effect on firm value.
\end{abstract}

Key words: good corporate governance, corporate social responsibility, firm value.

\section{Pendahuluan}

\section{Latar Belakang}

Salah satu tujuan setiap entitas/perusahaan ialah untuk memaksimumkan nilai perusahaan. Dengan memaksiumkan nilai perusahaan tersebut maka akan meningkatkan kemakmuran pemilik perusahaan. Nilai perusahaan akan menjadi sangat penting karena dengan nilai perusahaan yang tinggi akan diikuti dengan tingginya kemakmuran pemegang saham. Nilai perusahaan yang tinggi akan menjadi daya tarik tersendiri bagi investor untuk menanamkan modal di perusahaan tersebut. Sebaliknya, dengan rendahnya nilai suatu perusahaan akan mencerminkan rendahnya pula kemakmuran yang akan didapat oleh pemilik perusahaan. Selain itu, hal ini memungkinkan akan menjadi signal negatif kepada investor yang akan menanamkan modalnya.

Secara harfiah nilai perusahaan diukur melalui nilai pasar wajar harga saham. Dalam perusahaan yang go publik, indikator yang dapat digunakan dalam menilai suatu nilai perusahaan ialah harga saham yang diperjualbelikan baik pada pasar primer ataupun sekunder. Selain dicerminkan dengan nilai pasar saham di pasar, nilai perusahaan dapat diukur melalui price to book value (PBV). Price to book value ini ialah harga pasar saham dibandingkan dengan nilai buku saham. PBV kurang dari satu mencerminkan adanya sentimen negatif dan sebaliknya apabila lebih dari satu mencerminkan adanya sentimen positif. PBV yang tinggi menjadi keinginan para pemilik perusahaan sebab akan meningkatkan kemakmuran stakeholders.

Perusahaan melalui indikator PBV yang rendah mengindikasikan rendahnya tingkat kepercayaan investor terhadap kinerja keuangan serta prospek perusahaan. Nilai perusahaan yang rendah tidak dapat menarik investor untuk berinvestasi pada perusahaan. Hal ini berlaku sebaliknya, ketika nilai perusahaan tinggi akan menarik investor untuk berinvestasi pada perusahaan. Secara tidak langsung hal ini pun mencerminkan tingginya kepercayaan investor terhadap kinerja keuangan dan prospek perusahaan.

Sebuah perusahaan yang besar akan memungkinkan dikelola oleh bukan pemilik perusahaan melainkan oleh seorang manajer yang kemudian menjadi agen untuk menjalankan usaha pemilik (principal). Akibatnya memunculkan sebuah konflik kepentingan antara keduanya. 'Konflik kepentingan antara pemilik dan agen terjadi karena kemungkinan 
agen tidak selalu berbuat sesuai dengan kepentingan principal, sehingga memicu biaya keagenan (agency cost)' (Prasinta 2012).

Salah satu hal yang dianggap dapat membantu untuk meningkatkan nilai perusahaan dan menyelaraskan konflik kepentingan yang terjadi antara agen dan prinsipal ialah dengan adanya mekanisme good corporate governance (GCG). Dimana Corporate Governance perspektif kontemporer didasarkan pada persepsi bahwa perusahaan dapat memaksimalkan penciptaan nilai (value creation) dalam jangka panjang dengan menunaikan tanggung jawab terhadap semua pemangku kepentingan (Warsono,dkk : 2009, 4).

Salah satu lembaga yang sampai saat ini turut berperan aktif dalam hal pengembangan GCG di Indonesia ialah The Indonesian Institute for Corporate Governance. Kontribusi IICG sendiri dalam memasyarakatkan GCG di Indonesia meliputi kegiatankegiatan dalam bidang riset dan pemeringkatan, pendidikan dan pelatihan, publikasi dan promosi, serta konsultansi. CGPI melakukan riset dan pemeringkatan dengan hasil riset berupa skor dan indeks persepsi penerapan GCG pada perusahaan. Umumnya tahapan penilaian CGPI dilakukan melalui empat tahapan, yaitu self-assessment, kelengkapan dokumen, penyusunan makalah, dan observasi.

Pada dasarnya perusahaan yang menerapkan GCG ini mengharapkan untuk dapat menunjang guna meningkatkan nilai perusahaannya. Akan tetapi pada faktanya masih terdapat beberapa perusahaan yang menerapkan GCG serta mengikuti pemeringkatan CGPI masih mempunyai nilai perusahaan yang berfluktuasi dan bahkan beberapa perusahaan memiliki nilai rendah.

Selaindari GCG yang dapatmempengaruhinilaiperusahaanadalahCorporate Social Responsibility (CSR). Seperti yang diungkapkanolehDonatodanlzzobahwa"dewasa ini informasi mengenai CSRD juga mempengaruhi harga saham perusahaan" (Donato dan Izzo, 2012).Sehingga para investor menjadikan informasi kinerja perusahaan dalam bidang sosial sebagai salah satu bahan pertimbangannya untuk melakukan investasi pada saham perusahaan yang bersangkutan.

Pengungkapan tanggung jawab perusahaan (CSRD) di dalam laporan tahunan perusahaan merupakan bentuk komitmen bisnis perusahaan untuk berkontribusi positif terhadap aktivitas lingkungan, sosial dan masyarakat. CSRD dapat menunjukkan bahwa perusahaan tersebut adalah perusahaan yang memiliki life cycle business yang baik. Perusahaan yang tidak menjalankan CSR secara baik, dapat terancam keberlangsungan bisnisnya. Terdapat beberapa perusahaan di Indonesia yang bermasalah dan bahkan tidak mampu lagi meneruskan kegatan usahanya akibat menjalankan praktek tata kelola perusahaan yang burukdiantaranyaPT Indorayon, PT Maeras Soputan Mining, dan PT Lapindo Brantas.

Perhatian terhadapvCSR semakin meningkat ditambah dengan adanya peraturan pemerintah yang membahas mengenai CSR diantaranya adalah Undang-Undang Perseroan terbatas No.40 Pasal 74 tahun 2007, UU No.25 Tahun 2007 tentang Penanaman Modal, dan UU No.19 Tahun 2003 tentang BUMN.

Corporate Social Responsibility (CSR) merupakan tanggung jawab operasi bisnis/perusahaan yang berkomitmen tidak hanya untuk meningkatkan keuntungan perusahaan secara finansial, melainkan untuk pembangunan lingkungan sosial ekonomi. Elingkton mengembangkan CSR dalam konsep tripple bottom lines, yaitu pelaporan yang menyajikan informasi tentang kinerja ekonomi (profit), lingkungan (planet), dan sosial (people) dari suatu entitas perusahaan. Sedangkan Corporate Social responsibility Desclosure (CSRD) merupakan metode yang digunakan manajemen dalam berinteraksi dengan masyarakat secara luas untuk mempengaruhi persepsi luar masyarakat terhadap suatu organisasi atau perusahaan.

Reny Dyah Retno M. Dan Denies Priantinah dengan hasil penelitiannya GCG berpengaruh positif terhadap nilai perusahaan dengan size dan leverage sebagai variabel kontrol, dan Pengungkapan CSR berpengaruh positif tidak signifikan terhadap nilai 
perusahaan dengan size, leverage, profitabilitas dan jenis industri sebaga variabel kontrol, serta GCG dan pengungkapan CSR berpengaruh positif terhadap nilai perusahaan. Penelitian dari Wardoyo dan Theodora Martina Veronica yang berjudul "Pengaruh Good Corporate Governance, Corporate Social Responsibility \& Kinerja Keuangan Terhadap Nilai Perusahaan" dengan hasil Sedangkan ukuran dewan komisaris, independensi dewan komisaris, jumlah anggota komite audit dan CSR tidak memiliki pengaruh secara signifikan terhadap nilai perusahaan. Titi Suhartati, Sabar Warsini dan Nedsal Sixpiria melakukan sebuah penelitian dengan judul Pengaruh Pengungkapan Tanggung Jawab Sosial dan Praktik Tata Kelola Perusahaan terhadap Nilai Perusahaan. Objek dalam penelitian ini ialah perusahaan yang bergerak dibidang manufaktur yang terdaftar di Bursa Efek Indonesia selama tahun 2007-2008 dan mengungkapkan informasi kinerja lingkungan dalam laporan tahunan (annual report) pada tahun 2007-2008 sehingga diperoleh sampel sebanyak 31 perusahaan. Variabel yang digunakan terdiri dari variabel dependen, variabel independen dan variabel kontrol. Variabel dependen yaitu firm value yang diukur dengan Tobin's $Q$. Variabel Independent yang pertama yaitu pengungkapan CSR (CSR) yang diukur dengan angka indeks Corporate Social Responsibility Index (CSRI). Variabel Independent yang kedua yaitu GCG yang di proksikan dengan jumlah dewan komisaris (Board Size), Jumlah Komisaris Independent (Independent Board) dan Komite Audit (Board Committee). Variabel kontrol atas nilai perusahaan (firm value) yaitu umur perusahaan (Age), pertumbuhan penjualan perusahaan (Sales Growth) dan ukuran perusahaan (Size). Hasil dari penelitian ini menunjukkan 1) CSR berpengaruh positif terhadap nilai perusahaan, 2) Jumlah dewan komisaris independen berpengaruh negatif terhadap nilai perusahaan, 3) Jumlah dewan komisaris independent berpengaruh positif dan signifikan terhadap nilai perusahaan, 4) Jumlah komite dewan komisaris tidak signifikan berpengaruh terhadap nilai perusahaan, 5) Umur perusahaan berpengaruh positif dan signifikan terhadap nilai perusaaan, 6) Pertumbuhan penjualan berpengaruh positif dan signifikan terhadap nilai perusahaan, 7) Size tidak berpengaruh signifikan terhadap nilai perusahaan. Jo, Hoje (2011) dengan penelitiannya Corporate governance and Firm value: the impact of corporate Social responsibility menyatakan bahwa CSR berhubungan/berkorelasi positif dengan corporate governance dan mekanisme monitoring serta CSR berpengaruh positif terhadap nilai perusahaan.

Sebagaimana telah diungkapkan di atas bahwasannya telah ada beberapa penelitian yang bertujuan untuk mengetahui pengaruh GCG dan CSR terhadap nilai perusahaan. Maka hal ini mendorong peneliti untuk melakukan verifikasi ulang sehingga melakukan penelitian dengan judul Pengaruh good corporate governance dan corporate social responsibility terhadap nilai perusahaan.

\section{Rumusan Masalah}

Berdasarkan permasalahan yang telah dipaparkan di atas, pada penelitian ini rumusan masalah yang diajukan ialah sebagai berikut :
1)
Bagaimana deskripsi good corporate responsibility dan nilai perusahaan.
2) Bagaimana pengaruh good corporate governance,corporate social responsibility terhadap nilai perusahaan.

\section{Landasan Teori, Kerangka Pemikiran, Hipotesis}

\section{Nilai Perusahaan}

Salah satu tujuan perusahaan adalah memaksimumkan nilai perusahaan. Nilai perusahaan merupakan harga yang bersedia dibayar oleh calon pembeli apabila perusahaan tersebut dijual. (Husnan 2000). Dengan memaksimumkan nilaiperusahaan maka akan meningkatkan kemakmuran pemilik perusahaan. Semakiin tinggi nilai perusahaan semakin meningkat kemakmuran pemilik perusahaan (Martin, John D 2004:849) Nilai perusahaan dapat dilihat 
dari beberapa variabel kuantitatif diantaranya nilai buku, nilai pasar perusahaan, nilai appraisal, nilai arus kas yang diharapkan. Sedangkan menurut Weston dan Copeland (2008:244) penilaian perusahaan terdiri dari PER, Tobin's Q, PBV. Menurut Murhadi (2009:148) investor menggunakan PBV ini diantara karena nilai buku relatif stabil, adanya praktik akuntansi yang relatif standar diantara perusahaan-perusahaan menyebabkan PBV dapat dibandingkan antar berbagai perusahaan yang akhirnya dapat menjadi sinyal apakah perusahaan under atau overvalue.

\section{Good Corporate Governance}

Brigham dan Houston (2006:26) mengungkapkan bahwa hubungan keagenan (agency relatinship) terjadi ketika satu atau lebih individu, yang disebut sebagai prisipal menyewa individu atau rganisasi lain yang disebut dengan agen, untuk melakukan sejumlah jasa dan mendelegasikan kewenangan untuk membuat keputusan kepada agen tersebut. Hal tersebut menunjukan bahwa prinsipal yang merupakan pemegang saham mempercayakan pengellaan perusahaannya pada manajemen (agen). Adanya prisipal dan agen tersebut memicu konfilk diantara keduanya yang dikenal dengan teori keagenan. Hal tersebut terjadi karena perbedaan kepentingan antara prinsipal dan agen. Untuk mengatasi konflik tersebut maka dapat diterapkan good corporate goverment (GCG). GCG menurut Rezaee (2007) dalam Warsono dkk (2009:3) adalah ...is a process affected by legal, regulatory, contractual, and marketbased mechanism and best practise to create substansial shareholders value while prtecting the intersest of other sharehlders. Prinsip GCG tersebut diantaranya honesty, resilience, responsiveness, tranparency.

\section{Corporate Social Responsibility}

Gray et. al, (1996) dalam Hadi, Nor (2011:88) mengatakan bahwa legitimasi merupakan ...a system-oriented view of organizatin and society...permits us $t$ focus $n$ the role of infrmation and disclosure in the relationship between organization, the state, individuals and group. dengan demikian maka sebagai suatu sistem perusahaan harus kongruen dengan harapan masyarakat (Reny Diah 2012).Sehingga jika perusahaan tida peduli dengan lingkungan masyarakat sebagai salah satu stakeholdernya maka hal tersebut akan mengakibatkan protes dari masyarakat sehingga akan menurunkan legitimasi tersebut. Untuk mewujudkan hal tersebut maka perusahaan melakukan Corporate Social Responsibility (CSR). CSR merupakan tanggung jawab perusahaan atas opersional perusahaan terhadap lingkungan dan pihak lainnya sebagai stakeholdemya. Pengungkapan CSR menurut Gray et.al. (1995b) dalam Hasibuan (2001:16-17) menyebutkan tiga studi yaitu dicision usefulness studies, economic theory studies, dan social and political theory studies.

\section{Kerangka Pemikiran}

Peningkatan nilai perusahaan merupakan salah satu tujuan jangka panjang perusahaan. Nilai perusahaan merupakan nilai yang bersedia dibayar oleh pembeli pada saat djual (Husnan, 2006: 6). Meningkatkan nilai perusahaan merupakan peningkatan terhadap kemakmuran pemilik perusahaan. Semakin meningkat nilai perusahaan maka akan semakin tinggi kemakmuran yang diperleh pemilik perusahaan. Nilai perusahaan akan tercermin dalam harga pasar saham perusahaan, price book value (PBV), dan Tobin's $Q$.

Price to book value (PBV) merupakan harga pasar saham dibandingkan dengan nilai buku saham. PBV kurang dari satu mencerminkan adanya sentimen negatif dan sebaliknya apabila lebih dari satu mencerminkan adanya sentimen positif. Jika perusahaan memiliki PBV yang tinggi maka sentimen positif tersebut akan merupakan sinyal bagi investor untuk menanamkan modalnya diperusahaan tersebut dan sebaliknya.

Dalam usaha untuk meningkatkan nilai perusahaan tersebut terdapat konflik kepentingan antara pemilik perusahaan (principle)dan manajer sebagai pengelola (agent), karena pemilik perusahaan menggunakan orang/pihak lain untuk mengelola perusahaannya. Sehingga terjadi perbedaan kepentingan antara pemilik perusahaan dan 
pengelolanya (agent dan principle). Hal tersebut terjadi karena manajer mengutamakan kepentingan pribadi mereka sedangkan kepentingan manajer tersebut bertentangan dengan kepentingan pemilik, karena menurut pemilik kepentingan manajer akan menambah beban bagi perusahaan sehingga akan mengurangi keuntungan yang akan diperolehnya.

Untuk mengatasi konflik kepentingan tersebut maka diterapkanlah good corporate governance (GCG). GCG menurut The Indonesian Institute For Corporate Governance (IICG) hakekatnya merupakan struktur, sistem dan proses yang digunakan oleh organ perusahaan guna memberikan nilai tambah perusahaan secara berkesinambungan dalam jangka panjang'. Good corporate governance ini terdiri dari seperangkat sistem atau peraturan yang mengatur antar hubungan stakeholders perusahaan dalam mencapai tujuan perusahaan. Stakeholders disini dimaksudkan kepada investor, dewan direksi, dewan komisaris dan sebagainya. Manfaat penerapan GCG bagi perusahaan adalah seperti meningkatkan kinerja perusahaan, mengembalikan dan menambah kepercayaan investor sehingga investor akan merasa puas dengan kinerja perusahaan dan kemakmuran yang mereka dapat sebagai imbal hasil dari investasinya. Hal tersebut seperti yang diungkapkan Dey Report (1994) dalam Siallagan dan Machfoedz (2006) bahwa corporate governance yang efektif dalam jangka panjang dapat meningkatkan kinerja perusahaan dan menguntungkan para pemegang saham.

Berdasarkan Organization Economic Cooperation and Development (OECD) prinsip prinsip dasar dari GCG meliputi , fairness, transparancy , accountability, responsibility.Dengan diterapkannya GCG tersebut akan memiliki manfaat bagi perusahaan yaitu akan menurunkan agency cost, cost of capital, meningkatkan nilai perusahaan dan mendapatkan dukungan dari stakeholders.GCG dalampenelitian ini merupakan hasil perhitungan CGPI.

Faktor lain yang dapat mempengaruhi nilai perusahaan adalah corporate social responsibility (CSR).CSR merupakan tanggung jawab sosial yang diberikan oleh perusahaan kepada lingkungannya. Ini merupakan bentuk komitmen perusahaan untuk membangun kualitas kehidupan yang lebih baik dengan stakeholdersnya. Komitmen perusahaan ini dilaksanakan salah satunya untuk mengatasi kesenjangan sosial dan kerusakan lingkungan akibat operasional yang telah dilaksanakan perusahaan. Pengungkapan CSR dilaporkan dalam laporan keuangan tahunan perusahaan. Kemudian dilakukan perhitungan sehingga mengahsilkan CSRDI dari GRI. Dengan adanya CSR ini akan menambah brand image perusahaan, meningkatkan loyalitas konsumen dan lainlainnya sehingga akan meningkatkan penjualan produk perusahaan dengan demikian akan meningkatkan profitabilitas. Hal tersebut merupakan sinyal positif bagi investor untuk menanamkan modalnya di perusahaan. Dengan demikian maka nilai perusahaan pun akan meningkat.

\section{Hipotesis}

Hipotesis dalam penelitian ini adalah $\mathrm{H} 1$ : Good corporate governance berpengaruh positif terhadap nilai perusahaan. H2: Corporate sosial responsibility berpengaruh positif terhadap nilai perusahaan. H3:Good corporate governance dan corporate sosial responsibility berpengaruh positif terhadap nilai perusahaan."

\section{Metode Penelitian}

Metode dalam penelitian ini adalah metode deskriftif verifikatif. Metode ini mendeskripsikan GCG, CSR dan Nilai perusahaan dan menguji apakah terdapat pengaruh antara GCG dan CSR terhadapnilai perusahaan.Populasi dalam penelitian ini adalah perusahaan yang masuk dalam pemeringkatan GCG oleh CGPI. Pengambilan sampel dengan purposive sampling dengan kriteria perusahaan termasuk ke dalam CGPI berturutturut pada tahun 2009-2012dan mempublikasikan laporan keuangannya tersebut. Sampel yang digunakan sebanyak 12 perusahaan. Sumber data yang digunakan adalah laporan 
keuangan yaitu laporan keuangan periode 2009 - 2012. Teknik pengumpulan data menggunakan dokumentasi.

\section{Operasinalisasi variabel}

Dalam penelitian ini terdiri dari variabel independen X1 yaitu GCG dengan indikator skor CGPI, Variabel X2 yaitu pengungkapan CSR dengan indikator CSRI dan Variabel dependen (Y) adalah nilai perusahaan dengan indikator PBV.

\section{Teknik Analisis Data dan Pengujian Hipotesis}

Teknik analisis data yang digunakan adalah analisis regresi multiple dengan bantuan software SPSS V.20 for windows. Penggunaa analisis regresi multiple ini sebelumnya dilakukan uji asumsi klasik, yang terdiri atas uji linearitas, uji normalitas, uji multikolinearitas, heteroskesdasitas, dan autokorelasi. Pengujian hipotesis menggunakan Uji F dan Uji t.

\section{Hasil Penelitian dan Pembahasan}

Berdasarkan hasil tabel 1. Variabel GCG rata-rata tertinggi pada tahun 2012 dengan nilai 82,88. Hal ini menunjukkan bahwa penerapan GCG pada perusahaan semakin meningkat dari tahun ke tahun. Variabel CSR rata-rata tertinggi 2012 dengan nilai 0,48 hal ini menunjukkan bahwa perusahaan semakin kongruen terhadap harapan masyarakat. Dan variabel nilai perusasahaan dengan indikator PBV menunjukkan fluktuasi dengan rata-rata tertinggi 2010.

Tabel 1. Gambaran GCG, CSR dan PBV

\begin{tabular}{|c|l|r|r|r|r|}
\hline & & 2009 & \multicolumn{1}{c|}{2010} & 2011 & \multicolumn{1}{c|}{2012} \\
\hline \multirow{3}{*}{ GCG } & MIN & 69,42 & 70,73 & 75,68 & 67,4 \\
\cline { 2 - 6 } & MAX & 91,67 & 91,81 & 91,91 & 91,88 \\
\cline { 2 - 6 } & AVE & 82,74 & 83,26 & 83,79 & 82,88 \\
\hline \multirow{3}{*}{ CSR } & MIN & 0,08 & 0,08 & 0,08 & 0,1 \\
\cline { 2 - 6 } & MAX & 0,89 & 1 & 1 & 1 \\
\cline { 2 - 6 } & AVE & 0,31 & 0,47 & 0,47 & 0,48 \\
\hline \multirow{3}{*}{ PBV } & MIN & 0,82 & 0,79 & 0,52 & 0,39 \\
\cline { 2 - 6 } & MAX & 7,42 & 8,95 & 5,96 & 4,11 \\
\cline { 2 - 6 } & AVE & 2,77 & 3,55 & 2,58 & 2,14 \\
\hline \multirow{2}{*}{ Sumber: data diolah } & & & & \\
\hline
\end{tabular}

\section{Uji Linearitas}

Berdasarkan tabel 2 terlihat bahwa nilai DW hitung adalah sebesar 1,706, angka tersebut lebih besar dari nilai $\mathrm{dL}=1,46(\mathrm{DW}>\mathrm{dL})$ maka dapat disimpulkan bahwa data berbentuk linear.

Tabel 2

Model Summary

\begin{tabular}{|c|c|c|c|c|c|}
\hline Model & $\mathrm{R}$ & $\mathrm{R}$ Square & $\begin{array}{c}\text { Adjusted R } \\
\text { Square }\end{array}$ & $\begin{array}{c}\text { Std. Error of the } \\
\text { Estimate }\end{array}$ & Durbin-Watson \\
\hline 1 & $.436^{\mathrm{a}}$ & .190 & .154 & 1.57006 & 1.706 \\
\hline
\end{tabular}

a. Predictors: (Constant), CSR, GCG

b. Dependent Variable: PBV

\section{Uji Normalitas}


Berdasarkan grafik 1 terlihat bahwa data menyebar sekitar garis diagonal dan mengikuti garis diagonal sehingga dapat disimpulkan bahwa dalam penelitian ini data berdistribusi normal.

\section{Grafik 1. P-P Plot}

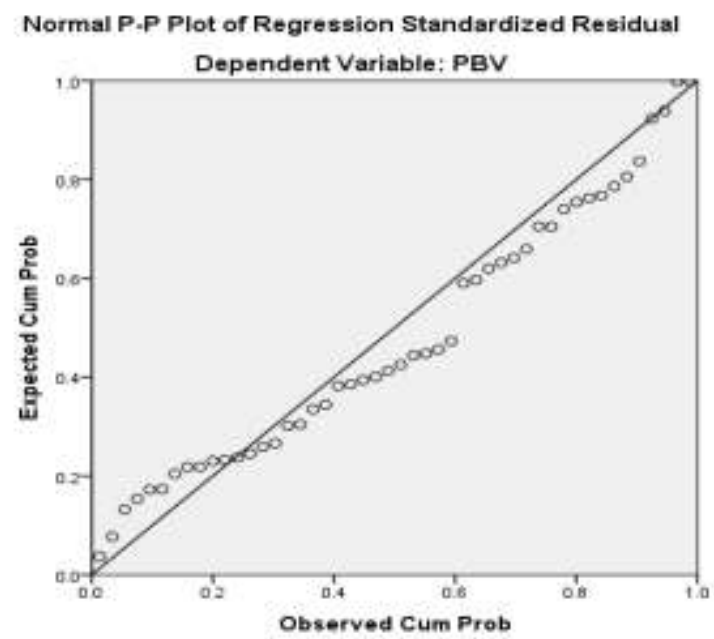

\section{Uji Heteroskedastisitas}

Dari grafik 2 terlihat bahwa titik data menyebar secara acak dibawah dan di atas angka nol pada sumbu y serta tidak membentuk pola tertentu. Hal ini dapat disimpulkan bahwa tidak terjadi masalah heteroskedastisitas pada model regresi dalam penelitian ini.

\section{Uji Multikolinearitas}

Dari tabel 3 menunjukkan bahwa semua nilai VIF kurang dari 10 dan Tolerance Value lebih dari 0,1 maka tidak terjadi multikolinieritas dalam model regresi. Hal ini menunjukkan bahwa variabel GCG dan CSR dapat dijadikan sebagai predictor.

\section{Uji Autokorelasi}

Dari tabel 4 terlihat bahwa nilai DW hitung adalah sebesar 1,706, angka tersebut lebih besar dari nilai $\mathrm{dU}=1,62(\mathrm{DW}>\mathrm{dU}$ ) maka dapat disimpulkan bahwa tidak terjadi autokorelasi dalam data tersebut

\section{Grafik 2}

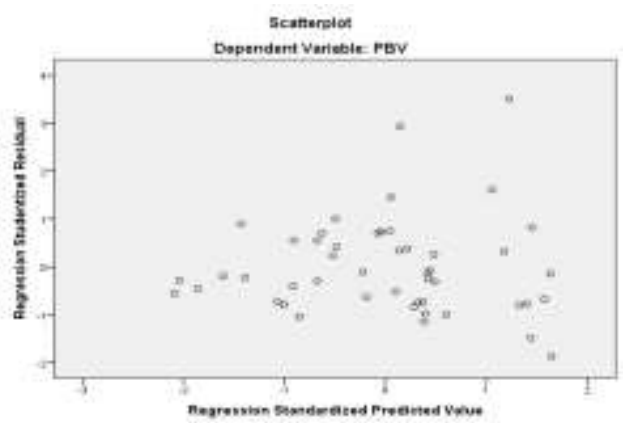

Tabel 3

Coefficients $^{\mathrm{a}}$ 


\begin{tabular}{|l|r|r|r|r|r|r|r|}
\hline & B & Std. Error & Beta & & & Tolerance & VIF \\
\hline \multirow{2}{*}{$\begin{array}{l}\text { (Constant) } \\
\text { 1 GCG }\end{array}$} & -3.811 & 2.830 & & -1.347 & .185 & & \\
& .071 & .034 & .282 & 2.076 & .044 & .978 & 1.023 \\
CSR & 1.479 & .686 & .292 & 2.155 & .037 & .978 & 1.023 \\
\hline
\end{tabular}

a. Dependent Variable: PBV

Tabel 4

Model Summaryb

\begin{tabular}{|l|r|r|r|r|r|}
\hline Model & $\mathrm{R}$ & $\mathrm{R}$ Square & \multicolumn{1}{c|}{$\begin{array}{c}\text { Adjusted R } \\
\text { Square }\end{array}$} & $\begin{array}{c}\text { Std. Error of the } \\
\text { Estimate }\end{array}$ & Durbin-Watson \\
\hline 1 & $.436^{\mathrm{a}}$ & .190 & .154 & 1.57006 & 1.706 \\
\hline
\end{tabular}

a. Predictors: (Constant), CSR, GCG

b. Dependent Variable: PBV

\section{Pengujian Regresi Berganda}

Berdasarkan hasil perhitungan regresi maka diperoleh persamaan sebagai berikut:

$$
Y=-3,811+0,071 G C G+1,479 \text { CSR }
$$

Dari persamaan regresi tersebut dihasilkan bahwa konstanta $-3,811$ berarti bahwa jika variabel $X 1$ dan $X 2$ sama dengan nol maka $Y=-3,811$. Koefisien $X 1=0,071$ maka $X 1$ berpengaruh positif terhadap $Y$ dan $X 2$ dengan kefisien 0,1479 maka $X 2$ berpengaruh positif terhadap $Y$

\section{UJI F}

Dari hasil pengujian diperoleh kesimpulan bahwa nilai $F_{\text {hitung }}$ yaitu 5,267 dan $F_{\text {tabel }}$ sebesar 3,20 maka dapat diketahui bahwa 5,267 > 3,20 ( $\left.F_{\text {hitung }}>F_{\text {tabel }}\right)$ sehingga $H_{0}$ diterima dan $\mathrm{H}_{1}$ ditolak. Hal tersebut menunjukkan bahwa regresi berarti, artinya variabel independen memiliki tingkat keberartian terhadap variabel dependen.

Tabel 5

ANOVA $^{\mathrm{a}}$

\begin{tabular}{|c|c|c|c|c|c|c|}
\hline \multicolumn{2}{|c|}{ Model } & Sum of Squares & $d f$ & Mean Square & $\mathrm{F}$ & Sig. \\
\hline \multirow{3}{*}{1} & Regression & 25.968 & 2 & 12.984 & 5.267 & $.009^{b}$ \\
\hline & Residual & 110.929 & 45 & 2.465 & & \\
\hline & Total & 136.897 & 47 & & & \\
\hline
\end{tabular}
a. Dependent Variable: PBV
b. Predictors: (Constant), CSR, GCG

UJl t

Tabel 6

Coefficients $^{a}$

\begin{tabular}{|c|c|c|c|c|c|c|c|}
\hline \multirow[t]{2}{*}{ Model } & \multicolumn{2}{|c|}{$\begin{array}{c}\text { Unstandardized } \\
\text { Coefficients }\end{array}$} & \multirow{2}{*}{$\begin{array}{c}\begin{array}{c}\text { Standardized } \\
\text { Coefficients }\end{array} \\
\text { Beta }\end{array}$} & \multirow[t]{2}{*}{$\mathrm{t}$} & \multirow[t]{2}{*}{ Sig. } & \multicolumn{2}{|c|}{ Collinearity Statistics } \\
\hline & $B$ & $\begin{array}{l}\text { Std. } \\
\text { Error }\end{array}$ & & & & Tolerance & VIF \\
\hline $1 \quad$ (Constant) & -3.811 & 2.830 & & -1.347 & .185 & & \\
\hline
\end{tabular}




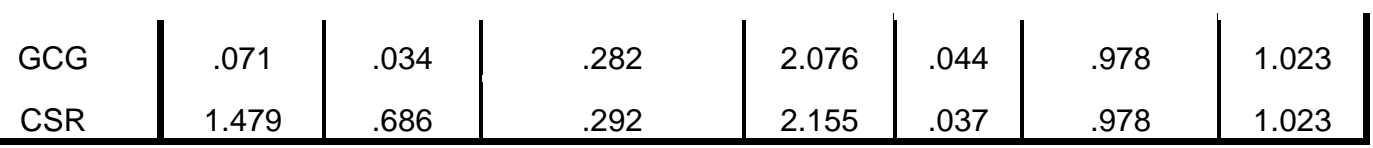

a. Dependent Variable: PBV

Berdasarkan hasilpengujian yang dilakukantersebut denganmenggunakanbantuan SPSS versi 20, menunjukkankesimpulansebagaiberikut

Tabel 7

KeputusanPengujianUji t

\begin{tabular}{|c|c|c|c|c|}
\hline Variabel & thitung & tabel & Sig & Keputusan \\
\hline$X_{1}($ GCG) & 2,076 & 1,679 & 0,044 & Ho ditolak \\
\hline$X_{2}(C S R)$ & 2,155 & 1,679 & 0,037 & Ho ditolak \\
\hline
\end{tabular}

Sumber :HasilPengolahan data dengan SPSS versi 20 (Data Diolah)

\section{Pembahasan}

Hipotesis yang pertama yaitu GCG berpengaruh positif terhadap nilai perusahaan diterima. Hal ini menunjukkan bahwa setiap terjadi peningkatan GCG maka nilai perusahaan akan meningkat.Koefisien X1 sebesar 0,071 menunjukan bahwa setiap kenaikan GCG satu satuan maka maka akan menambah nilai perusahaan sebesar 0,071.Dengan tingkat signifikansi 0,04 maka GCG berpengaruh positif signifikan terhadap nilai perusahaan. Hal ini terjadi karena dengan peningkatan GCG menunjukkan bahwa perusahaan sudah menerapkan GCG diperusahaan disebabkan karena adanya manfaat GCG yang dirasakan terutama manfaat jangka panjang dan bukan hanya untuk mematuhi perarturan semata tetapi memang penerapan GCG sudah menjadi salah satu kebutuhan perusahaan. Karena investor sekarang mulai menilai pelaksanaan GCG di perusahaan sebab dengan hal tersebut menunjukkan komitmen perusahaan untuk menjalakan perusahaan dengan tata kelola yang baik. Dan lingkungan di Indonesia yang mendukung untuk penerapan GCG di Perusahaan.

Hipotesis yang kedua bahwa CSR berpengaruh positif terhadapperusahaan dapat diterima. Hal ini menunjukkan bahwa semakin tinggi pengungkapan CSR maka nilai perusahaan akan semakin meningkat. Koefisien X2 sebesar 1,479 menunjukan bahwa setiap kenaikan pengungkapan CSR satu satuan maka maka akan menambah nilai perusahaan sebesar 1,479.Dengan tingkat signifikansi 0,037 maka CSR berpengaruh positif signifikan terhadap nilai perusahaan. Hal tersebut terjadi karena dengan pengungkapan CSR salah satu manfaatnya akan meningkatkan brand image perusahaan, meningkatkan loyalitas pelanggan dsb. Dengan demikian maka akan meningkatkan penjualan sehingga akan meningkatkan laba perusahaan. Peningkatan laba tersebut menunjukkan meningkatnya kinerja perusahaan, maka hal tersebut akan membuat investor tertarik untuk berinvestasi sehingga nilai perusahaan pun meningkat.

Hiptesis yang ketiga bahwa GCG dan pengungkapan CSR berpengaruh positif terhadap perusahaan diterima. Dengan tingkat signifikansi 0,009 maka GCG dan CSR berpengaruh positif signifikan terhadap nilai perusahaan. Hasil penelitian ini sejalan dengan penelitian Ni Nyoman G Martini Putu menunjukkan bahwa Corporate Social Responsibility, Corporate Governance, dan Ukuran perusahaan berpengaruh positif terhadap Profitabilitas, dan Mukhtarudin, Relasari, dan Messa Felmania penelitian ini menunjukkan bahwa dewan komisaris, dewan komisaris independen, pemilik intstitusional, pemilik manajerial dan komite audit dan pengungkapan CSR berpengaruh positif dan signifikan terhadap nilai perusahaan. Sedangkan dewan komisaris independen pengaruh negatif dan tidak signifikan terhadap nilai perusahaan.

\section{Kesimpulan dan Saran}


Berdasarkan hasilpenelitian tersebut maka dapat disimpulkan:

1. GCG dan pengungkapan CSR diperusahaan dan juga nilai perusahaan menunjukkan hasil yang fluktuasi.

2. GCG dan Pengungkapan CSR berpengaruh positif signifikan terhadap nilai perusahaan.

\section{Saran}

Terdapat beberapa keterbatasan dalam penelitian ini diantaranya adalah peride pengamatan dari tahun 2009-2012, dan jumlah data yang masih kurang yaitu 12 perusahaan dengan periode 2009-2012, dan terbatasnya variabel yang digunakan.

Berdasarkan hasil penelitian dan keterbatasan penelitian maka menyarakankan halhal sebagai berikut :

1. Bagi investor dan calon investor yang akan beinvestasi, GCG dan pengungkapan CSR dapat digunakan sebagai salah satu bahan pertimbangan dalam menilai perusahaan.

2. Bagi peneliti selanjutnya dapat menambah sampel dan periode penelitian, dan juga dapat menambah variabel lainnya yang dapat mempengaruhi nilai perusahaan.

\section{Daftar Pustaka}

Brigham dan Houston (2006).Dasar-dasar Manajemen Keuangan. Edisi 10 buku 1 Jakarta : Salemba Empat

Diah, Reny (2012). Good Corporate Governance dan Pengungkapan Corporate Social Responsibility terhadap nilai perusahaan, Jurnal Nominal, volume 1 nomor 1

Hadi, Nor (2011).Corporate Scial Resp[onsibility, Graha Ilmu,: Yogyakarta

Husnan, S., dan Enny Pudjiastuti.(2006). Dasar-dasar Manajemen Keuangan.Yogyakarta : BPFE Yogyakarta

Jo, Hoje dan Maretno A. Harjoto (2011) Corporate Governanceand Firm Value: The Impact of Corporate Social Responsibility. Journal of Business Ethic (2011) 103 : 351-383

Martin, John., William Petty, Arthur J. Keown and David F. Scott Jr., (2004) Manajemen Keuangan : prinsip-prinsip dan Aplikasi, edisi Kesembilan, Jakarta: PT Indeks.

Mukhtarudin, Relasari, dan Messa Felmania. (2014). Good Corporate Governance Mechanism, Corporate Social Responsibility Disclosure on Firm Value: Empirical Study on Listed Company in Indonesia Stock Exchange. International Journal of Finance \& Accounting Studies. ISSN 2203-4706. Vol. 2 No. 1; April 2014

Ni Wayan Rustriarini(2010) Pengaruh Corporate Governance pada hubungan Crporate scial responsibility dan nilai perusahaan. Simposium Nasinal Akuntansi XIII. AKPM-12

Ni Nyoman G Martini Putu, Moeljadi, Djumahir, Atim Djazuli. 2014. "Factors Affecting Firms Value of Indonesia Public Manufacturing Firms". International Journal of Business and Management Invention. ISSN (Online): 2319 - 8028. Volume 3 Issue 2ll February. 2014\|I PP.35-44. 
Prasinta, Dian. (2012). "Pengaruh Good Corporate Governance Terhadap Kinerja Keuangan". Accounting Analysis Journal. ISSN 2252-6765

R. Murhadi, Werner. (2009). Analisis Saham Pendekatan Fundamental. Jakarta : PT Indeks

Siallagan, Hamonangan dan Machfoedz, Mas'ud. (2006). Mekanisme Corporate Governance, Kualitas Laba dan Nilai Perusahaan. Simposium Nasional Akuntansi IX. Padang, 23-26 Agustus 2006.

Suhartati, Warsini, dan Sixpiria. 2011. Pengaruh Pengungkapan Tanggung Jawab Sosial dan Praktek Tata kelola perusahaan terhadap nilai perusahaan. JURNAL EKONOMI DAN BISNIS, VOL 10, NO. 2, DESEMBER 2011 : 95-105

Warsono, Sony. Dkk. (2009). Corporate Governance Concept and Model. Yogyakarta : CGCG FEB UGM

Wardoyo \& Veronika. (2013). Pengaruh Good Corporate Governance, Corporate Social Responsibility \& Kinerja Keuangan Terhadap Nilai Perusahaan. Jurnal Dinamika Manajemen. JDM Vol. 4, No. 2, 2013, pp: 132-149

Weston, J.F dan Copeland. (2008). Dasar-Dasar Manajemen Keuangan Jilid II. Jakarta : Erlangga.

Factbook idx

Perarturan Menteri BUMN No. Per-01?MBU/2011

Pedoman Umum GCG

UU Perseroan Terbatas No. 40 tahun 2007

UU Penanaman Modal No 25 tahun 2007

UU tentang BUMN No. 19 tahun 2003

www.idx.go.id

www.iicg.org 